\title{
Development and validation of a questionnaire to measure association factors with suicide.
}

Juliano Flávio Rubatino Rodrigues, ${ }^{1}$ Hannes Fischer, ${ }^{2}$ Spencer Luiz Marques Payão ${ }^{1}$

${ }^{1}$ Faculdade de Medicina de Marília (FAMEMA), Marília, SP, Brazil. ${ }^{2}$ Faculdade de Tecnologia de Pompéia (FATEC-Pompéia), Pompéia, SP, Brazil.

Email: julianofrr@terra.com.br

Phone: 14-3433-9673 / 14-99124-5645 (WhatsApp)

Address: Rua Dr. Augusto Barreto, 441 - Bairro Jardim Maria Izabel - Marília - SP / Brazil

CEP: $17.516-033$

Objective: Our goal is to develop an online questionnaire to survey the prevalence of suicidal behavior. Methods: We developed a questionnaire with 51 variables and proceeded with validations. Validations were performed using face validity, content validity, and construct validity. Reliability was performed by test-rest. Results: The face validity was 1.0 and the content validity was 0.91 . The exploratory factor analysis got $\mathrm{KMO}=0.86$ and extracted one principal factor. The confirmatory factor analysis demonstrates RMSEA $=0.000$ and $C F I=1.000$. The test-retest had an intraclass correlated coefficient of 0.98 . Conclusion: The adequate development questionnaire was validated, and we have an instrument to survey suicide behaviors in the pandemic time.

Keywords: Suicide; questionnaire; validity; reliability 


\section{1 - Introduction}

Alarmed by the constant and raising notices of suicide occurrences in Marilia in the past 4 years and by the inefficiency of every collective method of prevention used so far, it's noticed the need to perform a better study on the subject. It's known that suicide is an event of complex treatment in general and is related to many mental disorders such as depression, bipolar disorders, panic disorders, schizophrenia, personality disorders, and mental disorders correlated to substance abuse or dependence, and others.(1)

According to World Health Organization, 800,000 people committed suicide in the year 2015. (2) In Brazil, in that same year, there were 10,000 suicides, which is much lower $(5 / 100,000$ inhabitants $)$ than European countries $(20 / 100,000$ inhabitants).(3,4) The Brazilian cities that were described as having the highest risk of suicide in this same period were Taipas do Tocantins, in the State of Tocantins (79.68/100,000 inhabitants), Itaporã in the State of Mato Grosso $(75.15 / 100,000$ inhabitants), Mampituba in the State from Rio Grande do Sul $(52.98 / 100,000$ inhabitants), Paranhos in the State of Mato Grosso do Sul (52.41/100,000 inhabitants) and Monjolos in the State of Minas Gerais $(52.08 / 100,000)$.

Many questionnaires were found to assess the risk of suicide in the community. However, we believe that none of them present in all of their items the security to apply the questionnaire remotely and the completeness of our questions.(5)

Considering that no investigative instruments that can be fully replicated were found, a questionnaire was created. The questionnaire will address four life dimensions that may be related to the risk of suicide, what are the history of illnesses (psychiatric 
and general), the relationship with the primary support group (closest family), the relationship with the secondary support group (friends and others) and social occupation (schooling, work, religiosity, and others).(6, 7)

\section{2 - Objective:}

Our goal is to develop an online questionnaire to survey the prevalence of suicidal behavior.

\section{3 - Method:}

The study was approved by the FAMEMA Research Ethics Committee with the number: CAAE: 40205820.0.0000.5413. An informed consent form was developed.

Sample size calculation was based on confirmatory factor analysis. A number of 5 to 10 observations has been stipulated for each variable analyzed. The questionnaire was created with 51 variables. Thus, a sample of 255 to 510 observations was needed.

The questionnaire went through a long process of theorizing. Then, the variables were structured in the proper order. Data collection was done by online convenience sampling to avoid contact during these pandemic times.

The questionnaire went through all stages of validity and reliability. Validation was performed using face validity, content validity, and construct validity. Reliability was performed by test-rest. 


\section{4 - Results:}

\section{1 - Development:}

\subsection{1 - Theorization:}

As the first result of our research, we started to describe the foundation work for the development of our questionnaire, which, as will be seen, considering all facets of the theme from a historical rescue with its cultural, philosophical, psychological, sociological, medical, and other. We refer here to the main points that led us to reach an understanding of the issues necessary for our instrument.(8)

The earliest historical records of mankind report suicides.(9) The Old Testament records several suicides of Jews, of which we can cite the description in the First Book of Samuel, chapter 31, verse 4-6: "Saul said to his armor-bearer, 'Draw your sword and run me through, or these uncircumcised fellows will come and run me through and abuse me.' But his armor-bearer was terrified and would not do it; so Saul took his own sword and fell on it. When the armor-bearer saw that Saul was dead, he too fell on his sword and died with him. So Saul and his three sons and his armor-bearer and all his men died together that same day."(10) The non-acceptance of a defeat is an important item to be investigated in the social context and will be contextualized within some questions (questions 8 and 13).

The Greeks manifested themselves in antiquity in an ambiguous way when faced with suicide. Many of the ancient philosophers killed themselves.(9) Plato's dubious ideas had their anti-suicide stand reinforced throughout the Middle Ages in European Catholicism.(11) We can well observe them in the words of St. Augustine in his book The City of God from where we transcribed chapter 17 of the first book: 
"CHAPTER 17. OF SUICIDE COMMITTED THROUGH FEAR OF PUNISHMENT OR DISHONOR: And consequently, even if some of these virgins killed themselves to avoid such disgrace, who that has any human feeling would refuse to forgive them.? And as for those who would not put an end to their lives, lest they might seem to escape the crime of another by a sin of their own, he who lays this to their charge as a great wickedness is himself not guiltless of the fault of folly. For if it is not, lawful to take the law into our own hands, and slay even a guilty person, whose death no public sentence has warranted, then certainly he who kills himself is a homicide, and so much the guiltier of his own death, as he was more innocent of that offense for which he doomed himself to die. Do we justly execrate the deed of Judas, and does truth itself pronounce that by hanging himself he rather aggravated than expiated the guilt of that most iniquitous betrayal, since, by despairing of God's mercy in his sorrow that wrought death, he left to himself no place for a healing penitence? How much more ought he to abstain from laying violent hands on himself who has done nothing worthy of such a punishment! For Judas, when he killed himself, killed a wicked man; but he passed from this life chargeable not only with the death of Christ, but with his own: for though he killed himself on account of his crime, his killing himself was another crime. Why, then, should a man who has done no ill do ill to himself, and by killing himself kill the innocent to escape another's guilty act, and perpetrate upon himself a sin of his own, that the sin of another may not be perpetrated on him?"(12) The proximity of the suicide theme with religion since this time is already perceived, leading us to ask questions about this subject (numbers 21 and 22).

Dante, in describing the immortality of the human soul after death in 1472 , exerted such cultural influence that he changed the language of the Italian peninsula 
from Latin to the dialect spoken by the people of Florence, now known as Italian.(13)

The description of suicides in Hell triggered horrors:

"Canto tredicesimo:

\section{[...] Quando si parte l'anima feroce}

dal corpo ond'ella stessa s'è divelta,

Minòs la manda ala settima foce.

Cade in la selva, e non l'è parte scelta;

ma là dove fortuna la balestra,

quivi germoglia come gran di spelta.

Surge in vermena ed in pianta silvestre;

l'Arpie, pascendo poi delle sue foglie,

fanno dolore, e al dolor finestra[...]"1

The writer is usually a few steps ahead of the psychologist in describing the human being. The power of letters is so capable of influencing people that a wave of suicide swept Europe from 1774 with the publication of "The Sufferings of Young Werther" by Goethe.(14) This was not the author's intention, but romanticism brought a great need to study more about suicide.

Immanuel Kant was a divider of eras with his criticism. The publication of the "Critique of Pure Reason" in 1781 put on the table the three fundamentals unattainable directly by human beings.(15) Freedom, God and the immortality of the soul are only

\footnotetext{
1 "[...] When the exasperated soul abandons / The body whence it rent itself away, / Minos consigns it to the seventh abyss. / It falls into the forest, and no part / Is chosen for it; but where Fortune hurls it, / There like a grain of spelt it germinates. / It springs a sapling, and a forest tree; / The Harpies, feeding then upon its leaves, / Do pain create, and for the pain an outlet.[...]" in: Alighieri D. The Divine Comedy (Translator: Henry Wadsworth Longfellow) [internet]. [London (UK)]: Feedbooks; [date unknown]:55. Available In: https://www.holybooks.com/wp-content/uploads/Dante-Alighieri-The-Divine-Comedy.pdf
} 
attainable by criticism. These fundamentals are directly related to the possibility of suicide. As they are in the world of ideas, to adequately develop our questionnaire it is necessary to investigate what citizens think about them. (question 22)

None other than Arthur Schopenhauer brings to light the darkness of the human unconscious in 1818 in a work that would become one of the foundations of all Western thought. Although little read, "The world as will and representation" develops the existential sense with such lucidity that it highlights: "§ $16[\ldots]$ On the contrary, we find a complete contradiction in our wishing to live without suffering, a contradiction that is therefore implied by the frequently used phrase 'blessed life'[...] This contradiction is revealed in this ethic of pure reason itself by the fact that the Stoic is compelled to insert a recommendation of suicide in his guide to the blissful life (for this is what his ethics always remains)" [ ] "§54 [...] Conversely, whoever is oppressed by the burdens of life, whoever loves life and affirms it, but abhors its torments, and in particular can no longer endure the hard lot that has fallen to just him, cannot hope for deliverance from death, and cannot save himself through suicide." [ ] "§ 55 [...] Therefore in the greatest mental suffering men tear out their hair, beat their breasts, lacerate theirs faces, roll on the ground, for all these are only powerful means of distraction from an unbearable thought. Just because mental pain, being much greater, makes one insensible to physical pain, suicide becomes very easy for the person in despair or consumed by morbid depression, even when previously, in comfortable circumstances, he recoiled from the thought of it." [ ] "§ 57 [...] Further, the motives that induce suicide are so very different, that we cannot mention any misfortune which would be great enough to bring it about in any character with a high degree of probability, and few that would be so small that those like them would not at some time have caused it." [ ]" $\S$ 59 [...] The essential purport of the world-famous monologue in Hamlet is, in 
condensed form, that our state is so wretched that complete non-existence would be decidedly preferable to it. If suicide actually offered us this, so that the alternative 'to be or not to belay before us in the full sense of the words, it could be chosen unconditionally as a highly desirable termination ('a consummation devoutly to be wish'd'). There is something in us, however, which tells us that this is not so, that this is not the end of things, that death is not an absolute annihilation." [ ] " $\$ 65$ [...] Suicide, therefore, affords no escape; what everyone wills in his innermost being, that must he be; and what everyone is, is just what he wills." [ ] "§ 69 Suicide, the arbitrary doing away with the individual phenomenon, differs most widely from the denial of the willto-live, which is the only act of its freedom to appear in the phenomenon, and hence, as Asmus calls it, the transcendental change. The denial of the will has now been adequately discussed within the limits of our method of consideration. Far from being denial of the will, suicide is a phenomenon of the will's Strong affirmation. For denial has its essential nature in the fact that the pleasures of life, not its sorrows, are shunned. The suicide wills life, and is dissatisfied merely with the conditions on which it has come to him. [...] Thus the will-to-live appears just as much in this suicide (Shiva) as in the ease and comfort of self-preservation (Vishnu), and the sensual pleasure of procreation (Brahma). This is the inner meaning of the unity of the Trimurti which every human being entirely is, although in time it raises now one, now another of its three heads. As the individual thing is related to the Idea, so is suicide to the denial of the will. The suicide denies merely the individual, not the species. [...] Suffering approaches and, as such, offers the possibility of a denial of the will; but he rejects it by destroying the will's phenomenon, the body, so that the will may remain unbroken. This is the reason why almost all ethical systems, philosophical as well as religious, 
condemn suicide, though they themselves cannot state anything but strange and sophistical arguments for so doing."(16)

Schopenhauer's words make clear the complexity of the suicide theme by opening the unconscious universe and inviting human spirituality to the discussion. In that same century, deep debates took place about the human soul, culminating with the publication in 1857 of the "Spirits' Book", in which the spiritualist philosophy highlights the immortality of the soul and the impossibility of annihilation of the being.(17) These principles have been linked to the debate about suicide and much evidence suggests a search for spirituality based on the immortality of the soul as prevention for suicide.(18) In Brazilian literature many books describe the unfavorable reality of suicides after death, which demonstrates the important cultural role of this subject.(19) We included a direct question on this topic in the questionnaire (Question 22). The importance of the belief about the immortality of the soul can also be associated with suicide in some cultures that promise rewards to suicide bombers and also the possibility of the suicidal spirit transforming into the avenging demon of his executioner.(20)

Several social situations began to be more clearly related to suicide in the mid19th century. Karl Marx in his article "On Suicide" reports the mistreatment of women who eventually committed suicide.(21)

From the 1870s onwards, the West had a materialist and mechanistic uprising amid Nietzsche's great publications with his passionate Zarathustra and his superman.(22) It is a time to appreciate the here and now.(23) Answers are sought in quick aphorisms. Mankind started to quantify everything around them and in 1897 sociology received its foundational milestone with the publication of Le suicide by Émile Durkheim.(6) The role of the social masses in individual behavior and social 
representations are clearly described and correlated with suicide with the requirement to include questions in our investigation of them.(24) Questions about heroic and social behavior are inserted (questions 10, 18, and 19).

The 20th century begins with the repercussion of the maximum work of Sigmund Freud.(25) The interpretation of dreams disturbed the sleep of the Victorian era, and psychiatry starts to have a great interest in the human unconscious with Eugen Bleuler and his residency student, Carl Gustav Jung, who at the same time describes the case of a teenager, known as a spirits medium, in his somnambulism and deals with the theme as multiple personalities, putting to sleep the theme already attacked by the ideas of the philosopher Eduard von Hartmann, who defined mediumistic phenomena as the result of hallucinations. $(26,27)$ Jung's disciples continue the concepts of the archetypal symbols anima and animus in situations of suicidal ideation and emphasize the importance of understanding the individual's hopes for the immortality of the soul.(28)

The power of suggestion and symbology are worked out over the next few decades by the schools in Vienna and Zurich.(29) We believe it is important to use a question with symbols (question 21), inserted towards the end of the questionnaire, to suggest hope for those more "believing" people so that talking about the topic, which is even known not to be associated with risk, can be neutralized.(30) This question will be used to assess how much the power of belief may be more or less correlated with the risk of suicide. They will be quantified in images marked from 1 to 12 . Freud wrote little directly about suicide, however in his work "Grief and Melancholy" the theme is understood subliminally concerning the desire to destroy oneself in order to annihilate the pain caused by the introjected object.(31) Their statements already show the importance of correlating suicide with mental disorders (question 1 of the instrument). 
In the years following Freud's work, psychoanalysis has brought a great contribution to suicides in people with personality disorders, mainly related to violence in childhood, where questions on this topic are included in the questionnaire.(32)

The year 1942 was an important milestone in the clarification of the relationship between valuing the meaning of life and avoiding suicide. During the Second World War, the ideas of philosopher Albert Camus came off the press: "There is but one truly serious philosophical problem, and that is suicide. Judging whether life is or is not worth living amounts to answering the fundamental question or philosophy. All the rest whether or not the world has three dimensions, whether the mind has nine or twelve categories - comes afterward. [...] I therefore, conclude that the meaning of life is the most urgent of questions. How to answer it? [...] those who commit suicide were assured of the meaning of life."(33)

The psychiatrist Viktor Frankl was at that time a prisoner in the Auschwitz concentration camp and had the opportunity for three years to observe the different ways in which man deals with the absurdity of life.(34) This concept is developed by Camus in the "Myth of Sisyphus: essay on the absurd", where the struggle for life walks against the reality of death and choosing to live can be seen as absurd:

"the absurdity only makes sense insofar as it is not admitted".

Vitor Frankl develops all Logotherapy based on this concept. We believe that it is of fundamental importance to investigate the meaning of life and establish correlations with the risk of suicide. However, simply asking whether life makes sense may not answer the actual epistemological meaning of the question. Thus, indirectly, we bring the theme together into several issues. The meaning of life is directly associated with the way of living, which can be understood by the social and family context, etc. We formulate an open question (question 20) that gives rise to the 
description of life perspectives. The answer to this question will be quantitatively dichotomized into 0 - it is meaningless to live life; 1 - it makes sense to live.

In 1953 the American psychiatrist Harry Stack Sullivan publishes "The Interpersonal Theory of Psychiatry".(35) The perspectives of the meaning of life are directly related to interpersonal experiences. The meaning of life assumes much more a condition of feeling than a reason for being. Meaning is feeling. Those who live good human relationships feel better. Some questions are included in our questionnaire to describe the interpersonal relationships of citizens. (questions 5,12 to 19).

From the 1960s onwards and for the next 30 years, the American psychologist Edwin Shneidman founded Suicidology.(7) One of its main descriptions is the psychache or psychic pain, which describes enormous mental suffering in which suicide would have the role of erasing the consciousness that suffers. The strong correlations with mental disorders bring the need to use questions in our survey about them (questions 1, 3, 4, 9, and 10).

Psychopathology clearly understands that the risk of suicide increases from a simple idea of death to suicidal ideation, suicidal programming, and a suicide attempt.(36) Questions about each of these developments are included as main items (questions 2 and 3).

Questions of a demographic descriptive nature are included to establish possible correlations with the risk of suicide, such as level of education, occupational status, and sexual orientation (questions $6,7,8$, and 11). We believe that it is not useful to include a question about race or skin color due to great uncertainty with the answers collected.

Shneidman recalls the importance of the Greek term "Aristos" to define the need to alleviate suffering by seeking the best option.(7) Suicide, due to severe psychic pain 
caused by a problem, does not see a better solution than suicide. All questions aim to elucidate this relationship.

With the advance of neurobiological knowledge, many studies have sought to demonstrate the correlation between alterations in neuronal circuits and suicide.(37) Although a causal implication between these findings cannot be affirmed, as they can all be part of a broad diseased process of affective and cognitive disorders, dysfunctions in the serotoninergic, noradrenergic and glutamatergic systems are known to be present among suicidal individuals.(38) In the questionnaire, this evidence is considered in the questions of comorbidities.

\subsection{2 - Structuring:}

The language used in the questions was Portuguese. To have an adequate assessment of possible risk factors for suicide, the instrument was structured with open and closed questions. These use nominal, ordinal, and interval measurements. All questions were analyzed by quantitative methods. The structure of the questionnaire had 3 questions that directly address the topic of suicide with 6 divisions that together total 9 variables. Another 20 questions are included that unfold into 42 two variables that address all the factors theorized as important for this study. (Figure 1) 


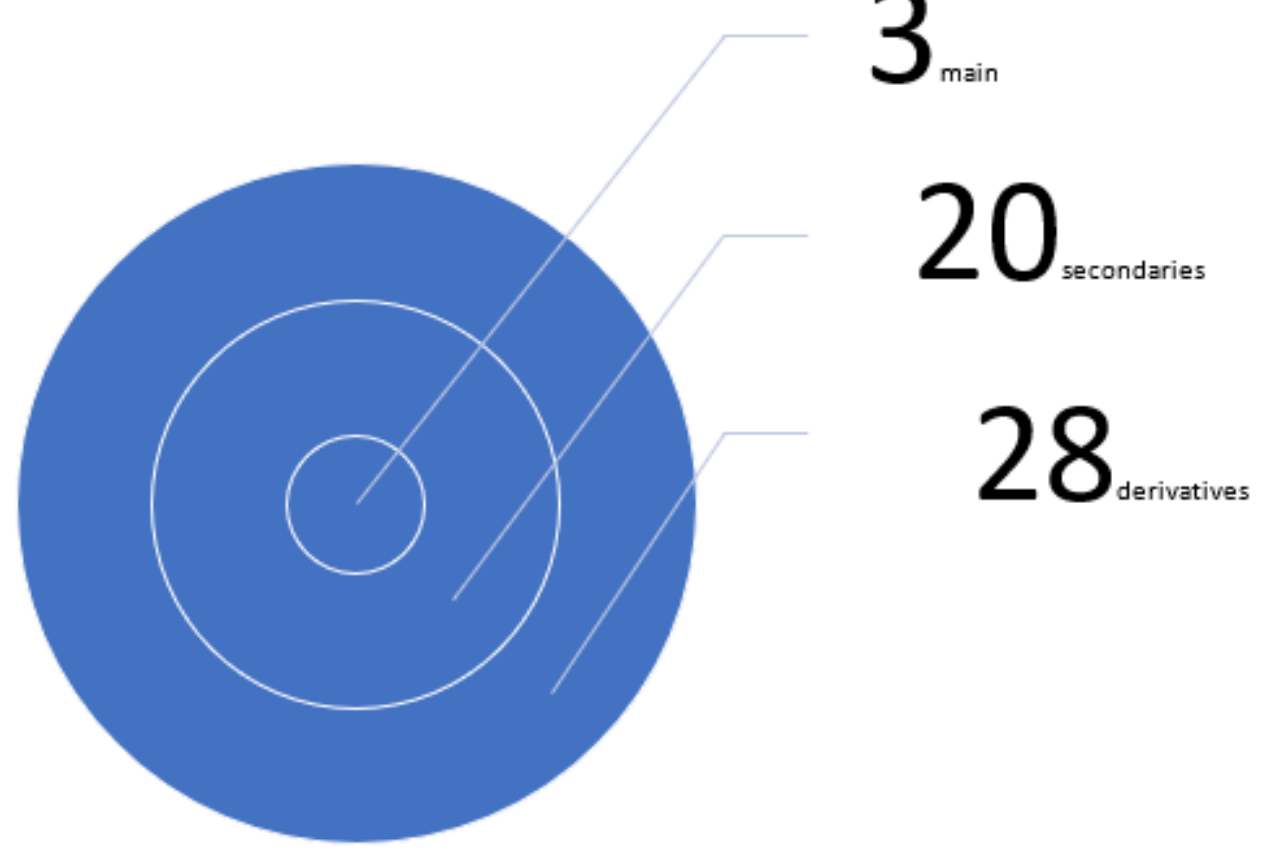

Figure 1 - Three main variables with six derivatives and twenty secondary variables with twenty-two secondary variables.

Questions that directly address the topic of suicide should take the lead in the instrument. They are formulated from a no-risk level to a higher risk. The question: "Você já conversou com algum sobre suicídio?"2 should take the first position. But we believe it is better to invert its position to the latter to demystify the popular common sense that one cannot talk about suicide and have the effect of deconstructing negative beliefs with the application of the questionnaire in people more vulnerable to suggestion, although there is no unfavorable evidence in this regard. We take the question about psychiatric treatment to the first question. Questions two and three address the topic of suicide with its derivations in an increasing degree of severity as proposed.

\footnotetext{
${ }^{2}$ Have you ever talked to anyone about suicide?
} 
In the middle part of the questionnaire, all items on comorbidities, education, and primary support group were inserted. The secondary support group approach and religiosity are inserted in the final stage of the questionnaire with the same objective of leaving a message of hope for those more suggestible people. The main constructs are listed in Figure 2.

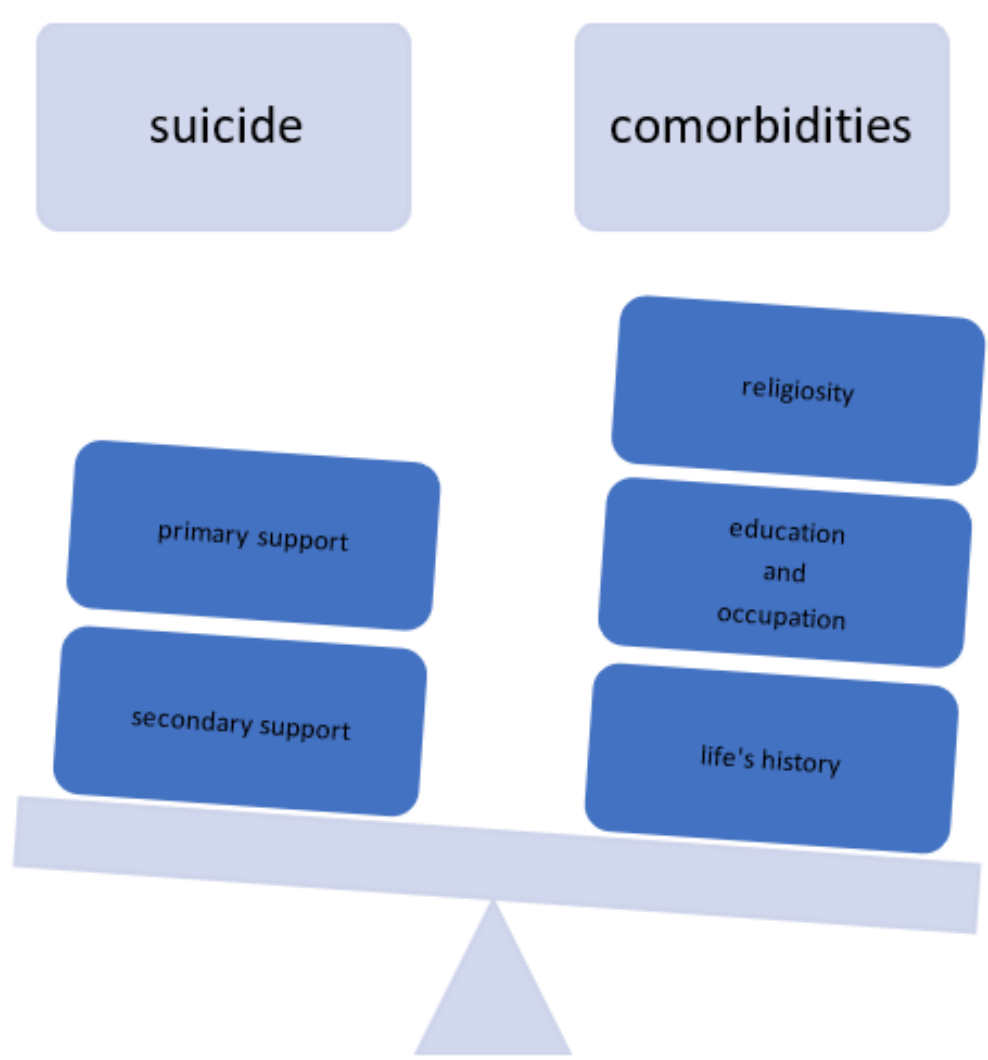

Figure 2 - Theoretical factors for the development of the questionnaire.

Although there were other constructs besides suicide in the questionnaire, it takes the "fragmented" form, since the other variables assume a unitary character of evaluation, not being considered in this instrument for prevalence studies their abstractions together.

\subsection{3 - Validity and Reliability:}




\subsubsection{1 - Face Validity:}

The questionnaire was applied to 10 patients in the office of one of the researchers. All answered the questionnaire in less than 15 minutes. None of them needed help to fill in and all answers were consistent with the questions.

\subsubsection{2 - Content Validity:}

The questionnaire was evaluated by two psychiatrists who have been working with suicidal people for over ten years. One of them showed an agreement of $86.9 \%$ and the other of $95.6 \%$. No questions or comments were made regarding the content of the disagreed questions. They only made suggestions in the formulation of the questions. In our understanding, the simplicity of some formulations is important to reach a large audience and not need the researcher's help to guide and clarify the answers. Therefore, we rejected the suggestions and accepted the agreement percentage of $91.3 \%$.

\subsubsection{3 - Construct Validation:}

A sample of 497 observations from the population group was used. Bartlett's Sphericity Test rejected the null hypothesis that the variables have a correlation of zero and the Kaiser-Meyer-Olkin measure was 0.86. Exploratory factor analysis was performed with all 51 variables using the principal component analysis method with rotation by oblimin with a selection of components with an eigenvalue greater than or equal to 1.17 factors were extracted (graph 1). The same analysis was performed using the maximum likelihood method with varimax rotation, also extracting 17 factors. Varimax rotation converged for 13 interactions, where the first factor brings together the variables of personal identification and the second the variables related to suicide. We emphasize that the two main factors are identical to the oblimin rotation in reverse order (Table 1). 


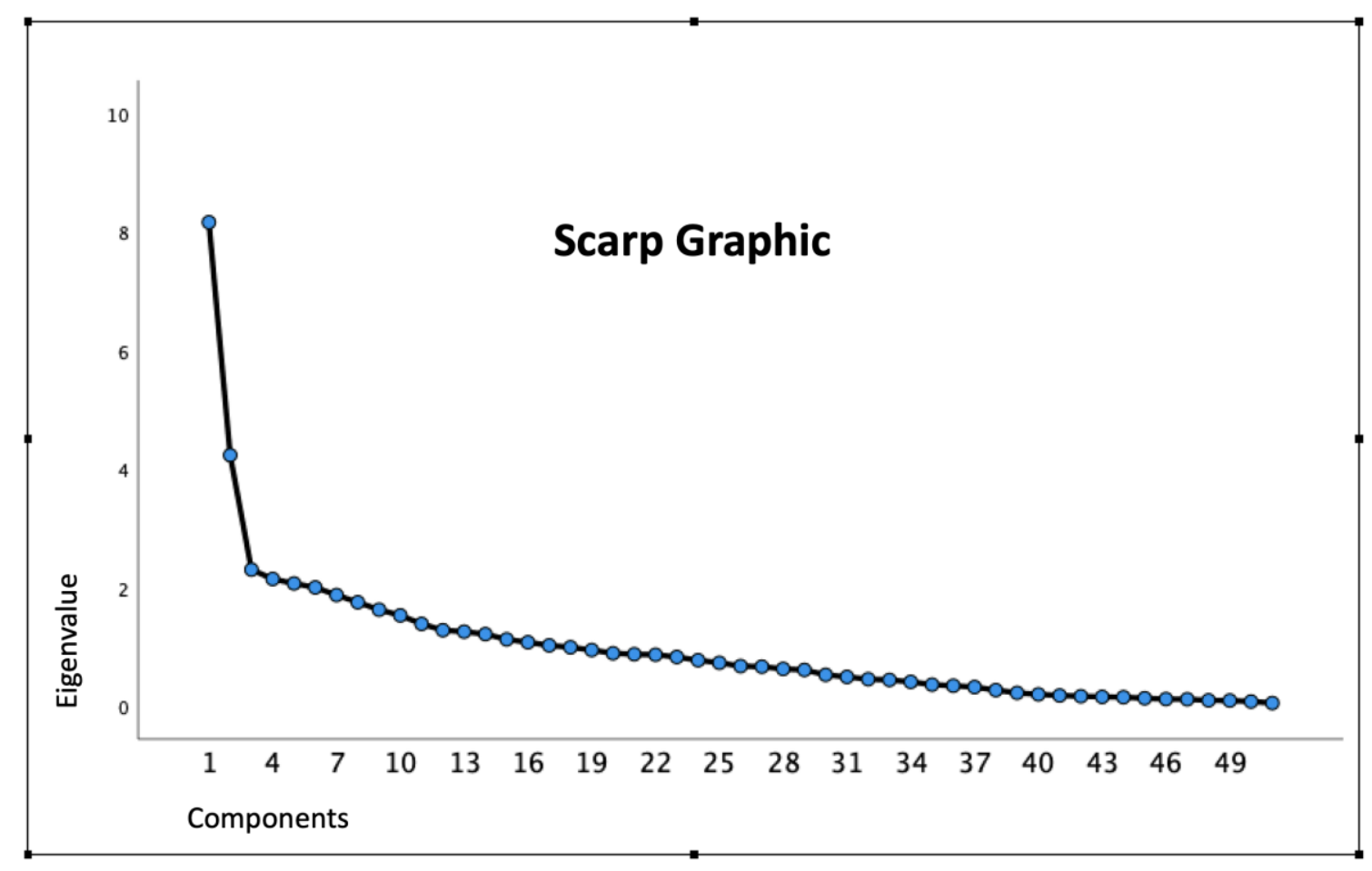

Graphic 1 - 17 components with an eigenvalue greater than or equal to 1 Table 1 - Two main factors extracted by maximum likelihood.

\begin{tabular}{|l|l|}
\hline \multicolumn{1}{|c|}{ Factor 1 } & \multicolumn{1}{|c|}{ Factor 2 } \\
\hline Date of birth & Question 2 \\
\hline Question 11 & Question 2A \\
\hline Question 12 & Question 2B \\
\hline Question 12A & Question 2C \\
\hline Question 12B & Question 2D \\
\hline Question 13 & Question 2E \\
\hline Question 17 & Question 3 \\
\hline Question 17A & \\
\hline Question 17B & \\
\hline
\end{tabular}

With the extraction of these factors, we started to perform Confirmatory Factor Analysis. For this, we initially recognized the questionnaire model for population 
survey, in which the existence of many factors found in the exploratory factor analysis has no meaning for validating this instrument since the only construct that interests us is that related to the suicide theme. All others are important for further correlation to prevalence studies.

Of the two main factors extracted by the exploratory factor analysis, one is related to the identification of people and the other to the theme of suicide. Therefore, only the second is of interest to us. Thus, we started to outline the 9 variables in Amos, version 27 , of the SPSS, abstracting four factors in a reflexive indicator model. The variables were analyzed using the maximum likelihood method, demonstrating an RMSEA of 0.064 and a CFI of 0.987 . To find the ideal construct, we included the correlations of the errors shown in Figure 3. With this, we obtained an RMSEA of 0.000 and a CFI of 1.000 (reference values: RMSEA $<0.08$ and $C F I>0.95$ ), thus validating the construct.(39) 


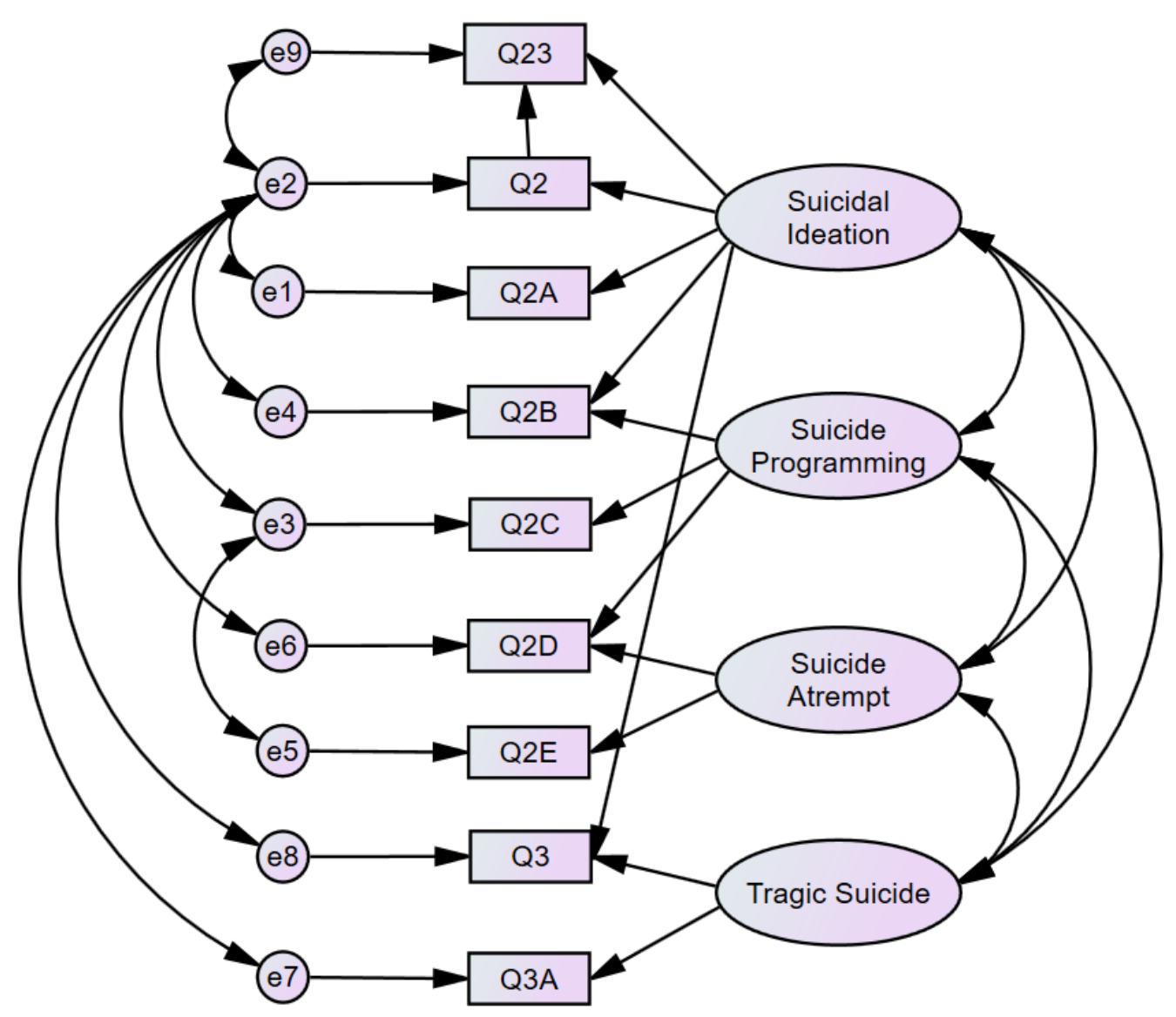

Figure 3 - Design for construct analysis.

\subsubsection{4 - Reliability:}

The online questionnaire was applied for 15 days, and 509 observations were obtained. We identified 11 people who answered the questionnaire twice. Of these, 10 responded identically and one of them was disregarded. One person answered the questionnaire differently and both answers were excluded. Of the remaining 497, the first 298 were considered the test, and the last 297 the retest. The test-retest demonstrated an intraclass correlation coefficient of 0.98 .

\section{5 - Discussion:}


Applying science in these pandemic times requires adaptations to the new normal. The development of an instrument for collecting population data needs to consider the need for social distancing. Given the growing need to study suicidal behavior in Brazil, the proposal for a new questionnaire that fits into this current context comes with profound relevance.

The most important step for the development of a work tool is the theoretical foundation. Without neglecting the important role of practical experience, it is known that an experienced bricklayer will find it easier to think about which anvil is best for his craft. Those who work directly with suicides when they come to bibliographic searches are clear about the breadth of the topic.

Suicide confronts health professionals with a vast amount of transdisciplinary knowledge. Only with the humility of an eternal apprentice is it possible to go to philosophy, sociology, theology, and other human sciences to understand the man who gives up on life. It was in this spirit that the team, over the course of a year, dedicated itself to many studies.

After a broad theoretical explanation, the structure considered the times of social isolation and the safety of applying the questionnaire through social networks. It was very important to understand the dynamics of the internet and virtual users. It is known that these pandemic times have required healthcare professionals to experience unprecedented online immersion. In Brazil, telemedicine was authorized. Research in the medical sciences is needed to follow this path.

Although we have used all validation protocols, it is recognized that construct validity is the gold standard. Evaluating a construct is not a passive procedure. On the contrary, it requires in-depth knowledge of the topic and the purpose of the instrument. Confirmatory factor analysis needs to be accompanied by observation intervals in 
which the language of numbers needs to be deciphered. After each reading, new analyzes need to be done. Fortunately, we now have powerful software to perform the calculations. Otherwise, this entire process would require more than a year.

Test-retest is often used in procedures to assess reliability. In some situations, it is advised to give a two-week interval between the test to the retest to remove the respondents' recall bias. We understand that this interval was not necessary for this virtual questionnaire understudy, as we were not working with the same respondents in the test and in the retest.

With a great deal of theorizing work that considered all aspects of the suicidal syndrome, the statistical validation analyzes presented no major difficulties along the way. The questionnaire proved to be a reliable tool for suicide prevalence studies.

\section{6 - Acknowledgments:}

We express our sincere gratitude to CAPES for providing bibliographic materials.

\section{7 - Disclosure:}

None.

\section{Referências bibliográficas:}

1. APA. Diagnostic and statistical manual of mental disorders, fifth edition. New York: APA; 2013. $510 \mathrm{p}$.

2. Bachmann S. Epidemiology of suicide and the Psychiatric Perspective. Int $\mathrm{J}$ Environ Res Public Health. 2018(15):1425.

3. Rodrigues CD, Souza DS, Rodrigues HM, Konstantyner TCRO. Trends in suicide rates in Brazil from 1997 to 2015. Braz J Psychiatry. 2019;41(5):380-8.

4. Junior DFM, Felzmburgh RM, Dias AB, Caribé AC, Bezerra-Filho S, MirandaSicppa Â. Suicide attempt in Brazil, 1998-2014: an ecologic study. BMC Public Health. 2016.

5. Silva TPS, Sougey EB. Escalas de avaliação do comportamento suicida em adolescentes da população geral Rev Bras Pesq Saúde. 2016;18(3):144-54.

6. Durkheim É. O suicídio: estudo de sociologia. 3a ed. São Paulo: WMF Martins Fontes; 2019. 515 p.

7. Scheidman E. Definition of suicide. Los Angelis: Interscience; 1985. 272 p.

8. Moreira JM. Questionários: Teoria e Prática. Coimbra: Almedina; 2009. 563 p.

9. Minois G. História do suicídio. São Paulo: Unesp; 2018. 414 p. 
10. Biblegateway. 1 Samuel 31:4-6. www.biblegateway.com [unknown]. p. https://www.biblegateway.com/passage/?search=1\%20Samuel\%2031\%3A4-

6\&version=NIV.

11. Plato. Complete works. Indianapolis: Hackett; 1997. 1808 p.

12. Saint Augustine. The City of God. Europe: http://www.documentacatholicaomnia.eu/; [unknown date]. p. 132.

13. Alighieri D. La Divina Commedia. 8a ed. Milano: BUR Rizzoli; 2016. 650 p.

14. Goethe JW. Os sofrimentos do jovem Werther. São Paulo: Abril; 2010.

15. Kant I. Crítica da Razão Pura. São Paulo: Martin Claret; 2009. 540 p.

16. Schopenhauer A. The World as will and representation. New York: Dever; 1969. $534 \mathrm{p.}$

17. Kardec A. O Livro dos Espíritos. 6a ed. Catanduva: Boa nova; 2009. 437 p.

18. Botega NJ. Crise Suicida: avaliação e manejo. Porto Alegre: Artmed; 2015. 302

p.

19. Pereira YA. Memórias de um suicída. 27a ed. Brasília: FEB; 2020. 542 p.

20. Barbagli M. O suicídio no Ocidente e no Oriente. Petrópolis, RJ: Vozes; 2019. 549 p.

21. Marx K. Sobre o suicídio. São Paulo: Boitempo; 2006. 83 p.

22. Nietzsche FW. Assim falava Zaratustra. São Paulo: Lafonte; 2012. 285 p.

23. Nietzsche F. Para além do bem e do mal: prelúdio a uma filosofia do futuro. São Paulo: Martin Claret; 2012. 239 p.

24. Bon GL. Psychologie des foules. Brussels: UltraLetters Publishing 2013. 145 p.

25. Freud S. A interpretação dos sonhos. Rio de Janeiro: Imago; 2006. 777 p.

26. Jung CG. Um caso de sonambulismo com carga hereditária (Médium espírita). Estudos psiquiátricos. 1. Petrópolis: Vozes; 1994. p. 28-103.

27. Hartmann KREv. Spiritism. London: Light; 1885.

28. Hillman J. Suicídio e alma. 4a ed. Petrópolis, RJ: Vozes; 2021. 223 p.

29. Jung CG. Símbolos da transformação: análise dos prelúdios de uma esquizofrenia. 9a ed. Petrópolis: Vozes; 2103. 653 p.

30. Gould MS, Marrocco FA, Klinman M. Evaluating latrogenic Risk of Youth Suicide Screening Programs: A Randomized Controlled Trial. JAMA. 2005;293(13):1635-43.

31. Freud S. Luto e melancolia. Edição Standard Brasileira das Obras Psicológicas Completas de Sigmund Freud. 14. Rio de Janeiro: Imago; 2006. p. 249-63.

32. Cassorla RMS. Estudos sobre suicídio: psicanálise e saúde mental. São Paulo: Blucher; 2021. $191 \mathrm{p}$.

33. Camus A. The Myth of Sisyphus. New York: Vintage; 1955. 56 p.

34. Frankl VE. Em busca de sentido: um psicólogo no campo de concentração. 34a ed. Petrópolis: Vozes; 2008.

35. Sullivan HS. The Interpersonal Theory of Psychiatry. New York: Norton; 1997. 36. Dalgalarrondo P. Psicopatologia e Semiologia dos Transtornos Mentais. Porto Alegra: Artmed; 2000. $271 \mathrm{p}$.

37. Bondoc EN, Marinescu D, Marinescu I, Mãlin RD, Stanca L, Zãvoi RE. Current understanding of psycho-neurobiology in depressive disorders with suicidal thoughts translational models. Rom J Morphol Embryol. 2019;60(2):389-402.

38. Pandey GN. Biological basis of suicide and suicidal behavior. Bipolar Disord. 2013;15(5):524-41.

39. Brown TA. Confirmatory Factor Analysis for Applied Research. 2nd ed. New York: Guilford. 462 p. 